\title{
Analisis Wacana Kritis Pengguna Narkoba di Rusia Berdasarkan Representasi Lirik Lagu Iuda Karya Dmitry Kuznetsov
}

\author{
Wizesa Nadewa Wasisrosa ${ }^{1}$, Mochamad Aviandy ${ }^{2}$ \\ ${ }^{1}$ Program Studi Rusia, Fakultas Ilmu Pengetahuan Budaya, Universitas Indonesia, \\ Jalan Margonda Raya, Depok, 16424 \\ ${ }^{2}$ Departemen Susastra, Fakultas Ilmu Pengetahuan Budaya, Universitas Indonesia, \\ Jalan Margonda Raya, Depok, 16424
}

Penulis untuk Korespondensi/E-mail: aviandy@ui.ac.id

\begin{abstract}
Abstrak - Artikel Penelitian ini membahas representasi pengguna narkoba berdasarkan lirik lagu Иyda (Iuda) milik rapper Rusia bernama Dmitry Kuznetsov atau Husky. Tujuan dari penelitian ini adalah untuk menjawab perumusan masalah perihal penemuan aspek yang merepresentasikan pengguna narkoba di Rusia berdasarkan lirik lagu Iuda pada periode pemerintahan Vladimir Putin di tahun 2012 hingga 2018. Penelitian ini menggunakan metode tiga dimensi analisis wacana kritis milik Norman Fairclough yang meliputi; analisis teks, praktik diskursif, dan praksis sosial-budaya. Kemudian peneliti menggunakan teori representasi Stuart Hall untuk melengkapi artikel penelitian ini. Melalui teori tersebut, ditemukan makna dari kalimat-kalimat tersirat yang merepresentasi pengguna narkoba yang diwakili oleh ketiga tokoh di dalam lirik tersebut, yaitu $J a, V y$, dan $T y$. Hasil penelitian ini membuktikan bahwa ketiga tokoh tersebut merupakan representasi pengguna narkoba. Hal ini menyebabkan pemerintah Rusia turun tangan dalam musik rap Rusia dengan cara mengendalikannya.
\end{abstract}

Abstract - This research examines the representation of drug users based on the lyrics of the song named Iuda by Russian rapper, Dmitry Kuznetsov. This research aims to discover the aspects that represent drug users in Russia based on the lyrics named Iuda in the period of Vladimir Putin's rule from 2012 to 2018. This research uses a three-dimensional critical discursive analysis method of Norman Fairclough's which includes; text analysis, discursive practices, and socio-cultural praxis. Then to complete this research, the researcher uses Stuart Hall's representation theory. Through this theory, discovered the meanings of the implied sentences that represent drug users are represented by the three characters in the lyrics, there are $J a, V y$, and $T y$. The results of this research prove that the three characters are drug user representations which resulted in the Russian government intervening in Russian rap music by controlling it.

Keywords - Critical Discourse Analysis; Rap; Representation; Song; Music

\section{PENDAHULUAN}

$\mathrm{K}$ ebijakan glasnost dan perestroika pada dekade 80-an telah membawa perubahan pada kehidupan masyarakat di Uni Soviet. Glasnost merupakan peningkatan keterbukaan dan transparansi dalam lembaga maupun pemerintah Rusia. Perestroika adalah restrukturasi dalam bidang ekonomi [1]. Kebijakan tersebut membawa berbagai jenis pemikiran dan kebudayaan baru, salah satunya musik rap. Sejak runtuhnya Uni Soviet dan berdirinya Federasi Rusia, musik rap semakin berkembang. Musik rap semakin dikenal dengan kemunculan grup musik Bad Balance yang merilis albumnya pada tahun 1994 [2].

Popularitas musik rap Rusia terus berkembang tiap tahunnya. Rusia sebagai negara demokrasi menjujung tinggi kebebasan berpendapat dan berbicara sesuai konstitusi Federasi Rusia pasal 29. Hal itu menyebabkan rapperา Rusia bebas untuk menyampaikan aspirasinya. Namun, pada tahun 2010, Ivan Alekseev, yang dikenal dengan sebutan Noize MC, ditangkap dan dipenjarakan selama 10 
hari di Volgograd. Hal tersebut dikarenakan konsernya yang dianggap "menyerang" penguasa. Konser tersebut menampilkan sebuah sandiwara mengenai kasus korupsi ekstrem yang dilakukan oleh pihak kepolisian Rusia [3]. Semenjak saat itu, rapper Rusia mulai melakukan protes terhadap pemerintah melalui karya-karyanya.

Setelah Vladimir Putin terpilih kembali sebagai Presiden di tahun 2018, pemerintah Rusia mulai memerhatikan lebih dalam mengenai perkembangan musik rap dan berusaha untuk mengambil peran besar untuk mengendalikannya. Putin memiliki kekhawatiran terhadap meningkatnya popularitas musik rap di Rusia. Hal tersebut didasari oleh pengaruh kuat dari musik rap terhadap generasi muda Rusia [4].

“...что рэп и прочее современное - на трёх китах: секс, наркотики и протест. Из всего этого, конечно, больше всего беспокоят наркотики. Это очевидная вещзь, это путь к деградаџии наџии...я согласен полностью: если невозможно остановить, то нужно возглавить и соответствуюшим образом направлять... хватать и не пущать - самый неэффективный, самый плохой."

“...bahwa musik rap dan budaya modern lainnya terbentuk dari tiga pilar: seks, narkotika, dan protes. Dari ketiga hal itu, tentu saja yang paling mengkhawatirkan adalah narkoba. Jelas ini adalah jalan menuju degradasi bangs saya setuju sepenuhnya: jika tidak mungkin untuk menghentikannya, maka Anda perlu menuntun dan membimbing secara tepat menangkap dan menahan adalah cara yang sangat tidak efisien, terburuk." (Putin, 2018).

Putin berupaya untuk menciptakan identitas nasional yang layak bagi rakyat Federasi Rusia dengan mempromosikan tradisi dan nilai-nilai lokal. Pemerintah menganggap bahwa musik rap yang digandrungi anak muda mengajarkan bunuh diri, satanisme, ekstremisme, dan penggunaan narkoba. [5]. Hal tersebut jelas bertentangan dengan tradisi dan nilai-nilai lokal. Oleh karena itu, musik rap di Rusia menghadapi gelombang pembatalan konser yang cukup masif [6]. Salah satunya adalah konser seorang rapper Rusia bernama Dmitry Kuznetsov atau Husky. Konsernya yang diadakan di kota Krasnodar dibatalkan tanpa alasan yang jelas oleh pihak otoritas. Kemudian pihak kepolisian menangkapnya atas tuduhan perusakan properti ketika bernyanyi di atap sebuah mobil. Dia mengaku melakukan hal tersebut untuk penggemarnya yang kecewa karena konser dibatalkan.

Husky berpenampilan sebagaimana umumnya rapper di Rusia. Namun, yang membedakannya adalah bagaimana cara dia menciptakan lirik. Dia mengambil beberapa referensi dari alkitab untuk menulis liriknya. Hal itu membuatnya kerap dibandingkan dengan penyair terkenal Rusia, Sergei Yesenin [7]. Husky juga dikenal dengan lirik lagunya yang ekstrem karena mengandung kebrutalan polisi, seks, narkoba, dan keinginan bunuh diri atau suicidal [6]. Salah satu lagunya yang dianggap ekstrem berjudul Iuda, yang berarti Yudas. Lagu yang telah dilihat oleh lebih dari tujuh juta penonton di Youtube itu telah diblokir atas permintaan pihak otoritas Rusia pada tanggal 19 November 2018. Musik video itu menyajikan tayangan berupa transaksi jual beli narkoba secara terang-terangan [6]. Berdasarkan latar belakang tersebut, penelitian ini membahas representasi pengguna narkoba di Rusia pada lirik lagu berjudul Iuda karya Dimitry Kuznetsov.

Terdapat beberapa penelitian terdahulu yang terkait dengan topik penelitian artikel jurnal ini. Penelitian pertama adalah artikel jurnal berjudul Kebijakan Pemerintah Terhadap Perkembangan Musik Rap di Rusia karya Annisa Dita Chetiska. Artikel jurnal ini dipublikasikan pada tahun 2019. Penelitian ini membahas kebijakan pemerintah Rusia terhadap perkembangan musik Rap di Federasi Rusia. Annisa menggunakan dokumen-dokumen negara pada laman daring dari Kantor Eksekutif Presiden kremlin.ru untuk menganalisis data yang dia dapatkan. Dalam penelitiannya, Annisa menjelaskan bahwa kebijakan budaya Rusia di masa Federasi, menyebabkan musik rap yang berasal dari Amerika masuk dan mengalami akulturasi dengan kebudayaan lokal Rusia. Peneliti menemukan topik yang sama dengan artikel jurnal milik Annisa. Namun dalam analisisnya, peneliti menemukan data yang rumpang. Annisa tidak menjelaskan secara terperinci mengenai lirik lagu yang diblokir pemerintah Rusia, yaitu Iuda karya Dmitry Kuznetsov. Berdasarkan hal tersebut peneliti akan menggunakan metode analisis wacana kritis untuk menganilisis lirik yang dimaksud.

Selanjutnya, artikel jurnal berjudul Diplomasi Budaya Melalui Песня Острова Пальм (Pesnja Ostrova Pal'm): Sebuah Analisis Wacana Kritis yang ditulis oleh Edelleit Rose Widyatmoko, seorang alumni Sastra Rusia Fakultas Ilmu Pengetahuan Budaya. Artikel ini dipublikasikan pada tahun 2019. 
Edelleit dalam artikel jurnalnya membahas aspek diplomasi budaya yang terdapat dalam lirik lagu Pesnja Ostrova Pal'm yang merupakan hasil alih bahasa lagu "Rayuan Pulau Kelapa" ke dalam bahasa Rusia. Hasil dari penelitian ini Edelleit menjelaskan bahwa pemilihan kata yang disajikan dalam Pesnja Ostrova Pal'm menunjukkan bahwa Rusia mengakui keindahan alam Indonesia dan ingin menjadi "sahabat" dalam membantu Indonesia yang saat itu sedang membutuhkan bantuan ekonomi. Jurnal ini menggunakan metode analisis wacana kritis dengan pendekatan model tiga dimensi milik Norman Fairclough. Metode tersebut merupakan pilihan yang tepat untuk menganalisis topik penelitian artikel jurnal peneliti yang berjudul Representasi Pengguna Narkoba dalam Lirik Lagu Iuda. Namun, untuk mengetahui bahwa lirik Iuda ini merepresentasikan pengguna narkoba, maka peneliti menggunakan teori representasi.

Penelitian milik Akhmad Nurismarsyah merupakan salah satu penelitian yang menggunakan metode analisis wacana kritis yang dipadukan dengan teori representasi. Penelitian tersebut berjudul Representasi Uni Soviet Dalam Учебник Русского языка/Ucebnik Russkogo Jazyka/'Buku Pelajaran Bahasa Rusia' «Русский Язык»/«Ruskij Jazyk» Terbitan Tahun 1976 yang dipublikasikan pada tahun 2010. Akhmad menggunakan teori representasi milik Stuart Hall untuk membuktikan, bahwa buku pelajaran bahasa Rusia tersebut merepresentasikan Uni Soviet. Hasilnya, Akhmad dapat membuktikan bahwa buku itu merepresentasikan Uni Soviet secara baik melalui penandaan-penandaan yang ditunjukkan teksnya.

Berdasarkan riset-riset yang telah dilakukan oleh penelitian terdahulu, peneliti akan membarui penelitian-penelitian tersebut dengan menggunakan topik berbeda, yaitu narkotika dan obat-obatan terlarang dalam lirik lagu Iuda karya Dmitry Kuznetsov. Data yang digunakan pada penelitian ini adalah lirik lagu berjudul Iuda karya Dmitry Kuznetsov yang diunduh di laman daring https://genius.com/Husky-judas-lyrics. Alasan peneliti memilih lirik melalui laman daring tersebut yaitu, terdapat beberapa anotasi yang telah diberikan mengenai lirik tersebut. Hal itu memudahkan peneliti untuk membuktikan bahwa lirik lagu Iuda merepresentasikan narkoba

\section{METODE}

Representasi merupakan produksi pemaknaan dari konsep di dalam pikiran yang disampaikan melalui bahasa, tanda, simbol, dan lain sebagainya [8]. Berdasarkan kutipan tersebut, [8] berkata bahwa representasi merupakan penghubung antara konsep dan bahasa yang dapat mengacu pada objek dunia nyata ataupun objek fiksi dunia imaji. Representasi juga merupakan praktik penandaan. Hal itu dihasilkan dari konstruksi dan produksi tanda yang membuatnya menjadi bermakna.

Terdapat dua proses dari sistem representasi, yaitu representasi yang terkait dengan mental dan yang terkait erat dengan bahasa [8]. Representasi merupakan sebuah sistem yang menghubungkan berbagai konsep atau representasi mental dalam pikiran manusia terhadap objek-objek di sekitarnya. Kemudian sistem tersebut menghasilkan bahasa yang dapat dimengerti oleh orang lain, baik berupa tekstual, lisan, gerak tubuh, suara-suara tertentu, maupun gambar. Kedua, representasi terkait erat dengan bahasa merupakan konsep dalam pikiran seorang manusia yang diproduksi menjadi bahasa dan dimengerti oleh orang lain.

Proses pemaknaan dipengaruhi oleh konteks sosial dan budaya [8]. Hal tersebut mengakibatkan muncul sebuah konsep pemaknaan terhadap sesuatu dan menimbulkan makna tidak langsung atau konotasi. Melalui hal ini, timbul hubungan antara identitas seseorang dengan benda yang digunakannya. Woodward (1999) mengatakan bahwa terdapat asosiasi identitas seseorang dengan yang dipakainya sehari-hari. Kemudian terdapat proses stereotyping di antara aspek identitas dan representasi. Stereotyping merupakan karakteristik yang dianggap terikat dengan seseorang

Penelitian ini menggunakan metode analisis wacana kritis secara analisis konteks untuk mengungkap makna dibalik lirik karya seorang rapper Rusia bernama Husky yang tertulis dalam bahasa Rusia. Wacana adalah praksis sosial dalam bentuk interaksi simbolis yang bisa terungkap dalam pembicaraan, tulisan, kial, gambar, diagram, film, ataupun musik [9]. Wacana juga memiliki empat unsur, yaitu adanya subjek yang menyatakan, kepada siapa disampaikan, adanya wahana atau dunia yang ingin direpresentasikan, dan terdapat temporalitas atau konteks waktu. 
Analisis wacana kritis atau critical discourse analysis adalah metode yang digunakan dalam penelitian ilmu-ilmu sosial dan budaya. Analisis wacana kritis juga merupakan sebuah cara untuk meneliti secara empirik hubungan wacana dengan hal-hal tersebut yang terjadi dalam lingkup sosial tertentu [10]. Analisis wacana kritis telah dikembangkan oleh Norman Fairclough dengan tujuan untuk memetakan analisis teks (baik teks lisan maupun tertulis) dan menganalisis konteks sosial secara sistematis. Singkatnya, analisis wacana kritis melihat hubungan antara praktik wacana, peristiwa dan teks, serta struktur sosial budaya yang lebih luas.

Eriyanto dalam Risdiyanto (2017) menarik kesimpulan dari tulisan Fairclough dan Wodak bahwa setidaknya terdapat lima indikator yang terdapat dalam analisis wacana kritis, yaitu tindakan, konteks, sejarah, kekuasaan, dan ideologi. Namun, peneliti dalam artikel jurnal ini hanya menggunakan tiga indikator, yaitu:

\section{Konteks}

[9] menganggap bahwa konteks memberikan pengaruh penting dalam analisis wacana kritis, karena analisis wacana kritis dianggap sebagai penghubung antara teks dan konteks sosial. Dalam hal ini, perlu diperhatikan konteks terhadap praktik sosial dan hubungan antar teks untuk memahami makna wacana dalam situasi tertentu. Tidak semua konteks dimasukkan ke dalam analisis, hanya beberapa yang relevan dan berpengaruh atas penafsiran teks saja yang dimasukkan.

\section{Kekuasaan}

Kekuasaan berarti suatu kelompok dominan memiliki kesempatan untuk mempengaruhi kelompok lain dan mengikuti apa yang diinginkan oleh kelompok dominan tersebut [11]. Mempengaruhi dapat juga diartikan sebagai kontrol, baik kontrol secara mental maupun psikis. Analisis wacana kritis berupaya melihat bagaimana kekuasaan ini terbentuk oleh kelompok sosial melalui teks.

\section{Ideologi}

Analisis wacana kritis juga bertujuan untuk melihat ideologi yang tersembunyi dalam penggunaan bahasa [11]. Ideologi merupakan suatu sudut pandang yang memberikan pandangan dan nilai terhadap kelompok sosial tertentu sesuai dengan ketertarikan mereka. Namun, seringkali ideologi disalahgunakan dan digunakan sebagai alat untuk mempengaruhi pemahaman seseorang akan realitas sosial yang salah. Dalam hal ini, dapat dikatakan bahwa analisis wacana kritis tidak selamanya objektif karena setiap analisis wacana tentunya akan memiliki sudut pandang dan ideologi masingmasing penelitinya.

Dalam penelitian ini, peneliti menggunakan model tiga dimensi analisis wacana kritis milik Norman Fairclough. Model analisis ini menekankan bahwa sebuah teks tidak dapat dianalisis atau diinterpretasi secara harfiah, namun harus dikaitkan dengan konteks sosial yang melatarbelakanginya [10]. [12] mencatat bahwa model tiga dimensi milik Norman Fairclough mencakup analisis teks, praktik diskursif, dan praksis sosial-budaya.

1. Dalam dimensi teks terdapat tiga hal mendasar yang perlu dianalisis, yaitu penggunaan kosakata yang terkait dengan makna tertentu, penggunaan istilah, dan metaforanya [12]. Singkatnya, menganalisis teks berfungsi untuk menunjukkan adanya representasi, relasi, dan identitas;

2. Kedua adalah praktik diskursif. Dimensi ini melihat ideologi yang mendasar bagaimana teks diproduksi dan diterima dalam masyarakat yang mencakup latar belakang pengetahuan, interpretasi, dan konteks;

3. Dimensi terakhir adalah praksis sosial-budaya. Dimensi ini melihat bagaimana konteks sosial mempengaruhi teks dan menggambarkan aktivitas sosial dalam praksis [12]. Hubungan dimensi ini dan teks dijembatani oleh bagaimana teks diproduksi atau ditafsirkan.

Langkah-langkah dalam penelitian ini digambarkan dalam tabel sebagai berikut:

Tabel 1. Langkah Penelitian

\begin{tabular}{ll}
\hline \multicolumn{3}{c}{ Langkah Penelitian } & \\
\hline Langkah 1 & $\begin{array}{l}\text { Mengumpulkan data } \\
\text { berupa teks atau lirik }\end{array}$ \\
& lagu berjudul Iuda \\
Langkah 2 & Mengumpulkan data \\
& penunjang sebagai \\
& referensi mengenai \\
& lirik lagu tersebut \\
& melalui studi pustaka \\
& perpustakaan maupun \\
& internet \\
& Menerjemahkan lirik \\
& lagu ke dalam Bahasa \\
Langkah 3 & Indonesia \\
& Mengolah lirik lagu \\
& menggunakan analisis \\
Langkana kritis tiga
\end{tabular}




\begin{tabular}{cl}
\hline Langkah Penelitian \\
\hline dimensi (Fairclough, \\
1994) untuk mencari \\
hubungan antara teks \\
dengan kondisi social \\
pencipta lagu dan \\
negara Rusia pada \\
masa kepemimpinan \\
Putin \\
Menyimpulkan hasil \\
penelitian \\
\hline
\end{tabular}

\section{HASIL DAN PEMBAHASAN}

\section{Hasil Terjemahan}

Скит

И как-то так выходит, что без этого... ну, mbl не можешь жить. Это как пищуа, как воздух...

\section{Интро \\ Иуда (4x)}

Куплет 1

Обстоятельно проблевавшись

В чьей-то хате на Патриариих

Я вбиваю бычки в перила

Ожидая свой Киа Рио

Пусть в такси шепелявит ретро

Мы с водилой раздавим пятку

И до дома доедем всмятку, а

\section{Припев}

Мухи в бокале вина, а

Что будет после меня, а

Мультики нового дня, а

Вряд ли разделят со мной, ой

Кто из вас вылдаст меня, а

Кто из вас выдаст меня, а

Кто из вас выдаст меня, а

Ocmыть не успеет косой, ой, ой

Иуда

\section{Куплет 2}

Люди липнут как козинаки

Будь то лифт или Газенваген

Дорогуша, вы обознались

Мне не нужен психоанализ

Вы простите меня, утырка:

Мне скучны ваша мелодрама, ваша течка и ваша дырка (a)

\section{(Припев 1)}

Куплет 3

В моём плеере педерасть

A на проводе террористь

Я читаю для тех, кто бродит

По рукам или по этапам

Я не требую понимания

Лишь один из шального люда

Понимает меня Иуда

Припев 2

Мухи в бокале вина, а

Что будет после меня, а

Мультики нового дня, $а$

Tын не разделишь со мной, ой

Кто из вас выдаст меня, а

Кто из вас выдаст меня, а

Кто-то заложит меня, а

Ocmbıть не успеет косой, ой

Целую тебя, Иуда Pra-intro

Dan entah bagaimana, ternyata tanpa itu... ya, kamu tidak bisa hidup. Barang itu bagaikan makanan dan udara...

Intro

Yudas $(4 \mathrm{x})$

Bait 1

(Anda) benar-benar muntah

Di rumah seseorang, di distrik Patriach

Aku memadamkan rokokku di pegangan tangga

Menunggu mobil Kia Rioku

Biarkan retrofm yang tidak jelas itu berbunyi

Kita linting rokok ini bersama supir

Dan sampai rumah dalam keadaan kacau, a

Refrain 1

Lalat di dalam sebuah gelas wine, a

Apa yang akan terjadi padaku?, a

Animasi di hari baru, a

Tidak akan dibagikan dengaku, oy

Siapa dari kalian yang akan menyerahkanku, a

Siapa dari kalian yang akan menyerahkanku, a

Siapa dari kalian yang akan menyerahkanku, a

Tenang, si mata jereng tidak akan berhasil, oy, oy Yudas

Bait 2

Orang-orang terjebak seperti Kozinaki

Seolah-olah seperti di lift ataupun Gazenvagen

Sayang, Anda telah salah mengira aku sebagai orang lain

Aku tidak memerlukan psikoanalis

Anda memaafkanku, orang tidak berguna:

Aku bosan dengan melodramamu, gairah seksualmu, dan vaginamu (a) 


\section{(Refrain 1)}

\section{Bait 3}

Homoseksual di dalam MP3ku

Ada teroris di kabelnya

Aku membaca untuk mereka yang mengembara

Dengan tangan ataupun dengan bertahap

Aku tidak memaksa untuk dimengerti

Hanya satu dari orang-orang gila ini,

Mengerti aku, Yudas

\section{Refrain 2}

Lalat di dalam sebuah gelas wine, a

Apa yang akan terjadi padaku?, a

Animasi di hari baru, a

Tidak akan dibagikan dengaku, oy

Siapa dari kalian yang akan menyerahkanku, a

Siapa dari kalian yang akan menyerahkanku, a

Seseorang akan mengkhianatiku, a

Tenang, si mata jereng tidak akan berhasil, oy

$\mathrm{Ku}$ cium kamu, Yudas

Setelah menerjemahkan lirik lagu berjudul Iuda tersebut, peneliti menemukan beberapa keunikan dalam penggunaan kosakata yang dipakai Husky untuk menjelaskan makna yang ingin ia sampaikan

1. Penggunaan kata $\mathrm{Vy}$ dan Ty pada lirik.

Husky menggunakan dua kata yang berarti "kamu/Anda" di dalam lagu Iuda tersebut. Secara harfiah, kata Vy dan Ty mempunyai makna yang berbeda. Ty adalah kata ganti untuk orang kedua yang mempunyai makna "kamu" dan digunakan secara informal. Vy adalah kata ganti untuk orang kedua yang mempunyai makna "Anda" atau "kalian" dan digunakan dalam bahasa formal.

Dalam lirik lagu tersebut, Husky menggunakan kata ganti orang kedua Ty untuk mengganti kata Iuda atau Yudas. Yudas merupakan tokoh yang ada pada lirik lagunya tersebut. Sedangkan kata Vy hampir ada dalam setiap bait. Kata ganti untuk orang kedua Vy dia gunakan untuk orang-orang yang mengerti dirinya.

\section{Istilah-istilah Unik}

Di dalam lirik lagu Iuda ini, Husky banyak menggunakan istilah yang cukup asing. Salah satunya adalah kata pjatku pada bait pertama baris ke-enam yang peneliti terjemahkan menjadi rokok lintingan atau ganja. Terjemahan tersebut didapatkan dari kata slang Kazahkstan Utara untuk narkoba jenis ganja.

\section{Hasil Analisis Teks}

Analisis teks merupakan tahap pertama dalam metode penelitian analisis wacana kritis. Dalam menganalisis lirik lagu Iuda, peneliti membagi fokus analisis menjadi (1) pra-intro; (2) intro; (3) bait satu, (4) refrain satu; (5) bait dua; (6) bait tiga; dan (7) refrain dua.

Pra-intro

Скит

И как-то так выходит, что без этого... ну, mbl не можешь жить. Это как пища, как воздух...

Skit

I kak-to tak vyhodit, chto bez jetogo... nu, ty ne mozhesh' zhit'. Jeto kak pishha, kak vozduh...

Lagu ini diawali oleh dua kalimat yang runut. Kalimat pertama pada baris ini merupakan acuan untuk kalimat setelahnya. Kalimat i kak-to tak vyxodit, chto bez etogo... nu, ty ne mozhesh' zhit' (Dan entah bagaimana, ternyata tanpa itu... ya, kamu tidak bisa hidup) menjadi acuan untuk kalimat Eto kak pishcha, kak vozdux... (barang itu bagaikan makanan dan udara), namun pada kalimat i kak-to tak vyxodit, chto bez etogo tidak terdapat subjek yang jelas dan untuk memahami hal tersebut diperlukan inferensi yang bergantung pada pengetahuan yang muncul berdasarkan asumsi [13].

Berdasarkan asumsi, peneliti melihat bahwa subjek yang dimaksud oleh baris awal pada kalimat pertama adalah narkotika yang mengacu pada kata kerja vyxodit yang merupakan kata kerja infinitif bentuk masa kini dari on/ona. Lalu, untuk memperjelas maksud dari kalimat tersebut, dapat dilihat dari kalimat setelahnya, yaitu nu, ty ne mozhesh' zhit', yang mempunyai kata ty lalu diikuti dengan kata kerja masa kini mozhesh' dan kata kerja infinitif zhit', dan kalimat tersebut merupakan kalimat negasi karena memiliki partikel ne. Hal tersebut semakin memperkuat asumsi peneliti bahwa subjek yang dimaksud adalah narkotika ketika melihat terjemahan dari kedua kalimat tersebut mengacu pada sifat candu manusia.

Intro

Иуда (diulang 4 kali) Iuda (diulang 4 kali)

Pada intro, Husky hanya menyebut nama Iuda secara repetitif sebanyak empat kali atau disebut dengan anafora. Kata Iuda sendiri merupakan kata benda muzhkoi rod dengan kasus imenitel'nyi atau kasus pertama karena berdiri sendiri. 
Bait Satu

Обстоятельно проблевавшись

В чьей-то хате на Патриарших

Я вбиваю бычки в перила

Ожидая свой Киа Рио

Пусть в такси шепелявит ретро

Мы с водилой раздавим пятку

И до дома доедем всмятку,

Obstojatel'no problevavshis'

V ch'ej-to hate na Patriarshih

Ja vbivaju bychki v perila

Ozhidaja svoj Kia Rio

Pust' v taksi shepeljavit retro

My s vodiloj razdavim pjatku

I do doma doedem vsmjatku, a

Baris pertama dalam bait kedua memiliki kata kerja problevavshis' dengan kelas kata deeprichastie yang mengalami pelesapan subjek Vy (Anda), serta baris kedua merupakan kalimat keterangan tempat karena terdapat preposisi $\mathrm{v}$ dan na yang masih mengacu pada baris pertama. Pada baris keempat terdapat kata ganti benda svoj yang merujuk pada kata ganti benda Ja (aku) yang juga merupakan subjek pada baris ketiga.

Pada baris kelima terdapat kata kerja shepeljavit (berbunyi tidak jelas) yang merupakan kata kerja kala kini dari on/ona (dia). Lalu pada baris ke-enam tertulis jelas mestoimenie my (kita) diikuti dengan kata kerja bentuk kala kini razdavim (hancurkan) dan kata benda pjatku (rokok lintingan) yang terkena kasus akusatif. Baris ke-tujuh memiliki bentuk kalimat yang sama dengan baris ke-enam, namun kata ganti benda pada kalimat ini dilesapkan oleh kata kerja yang akan datang, yaitu doedem (akan sampai).

Refrain Satu

Мухи в бокале вина, а

Что будет после меня, а

Мультики нового дня, $а$

Вряд ли разделят со мной, ой

Кто из вас выдаст меня, a (diulang 3 kali)

Ocтыльт не успеет косой, ой, ой

Иуда

Muhi v bokale vina, a

Chto budet posle menja, a

Mul'tiki novogo dnja, a

Vrjad li razdeljat so mnoj, oj

Kto iz vas vydast menja, a (diulang 3 kali)

Ostyt' ne uspeet kosoj, oj, oj

Iuda
Muhi (lalat) merupakan subjek pada kalimat baris pertama yang diikuti keterangan tempat. Kalimat baris pertama merupakan metafora. Pada baris kedua terdapat kata kerja yang akan datang, yaitu budet (akan) dan menja (aku) yang merupakan kata ganti orang kasus genetif. Baris ke-tiga merupakan metafora. Kata ganti orang kasus instrumental mnoj (aku) terdapat pada baris ke-empat.

Bait Dua

Люди липнут как козинаки

Будь то лифт или Газенваген

Дорогуша, вы обознались

Мне не нужен психоанализ

Вы простите меня, утырка:

Мне скучны ваша мелодрама, ваша течка и ваша дырка

(a) Ljudi lipnut kak kozinaki

Bud' to lift ili Gazenvagen

Dorogusha, vy oboznalis'

Mne ne nuzhen psihoanaliz

Vy prostite menja, utyrka:

Mne skuchny vasha melodrama, vasha techka i vasha dyrka (a)

Pada baris pertama ini Ljudi (orang-orang) merupakan subjek bentuk jamak yang menjadi acuan untuk kata kerja masa kini lipnut (melekat). Baris ketiga dan kelima mempunyai kata Vy (Anda) yang merujuk pada kata utyrka (orang-orang tidak berguna atau pecandu narkoba yang tidak berguna). Kata vasha (dari kata Vy yang terkena kasus genetif atau kepemilikian) yang terkena konjugasi dari kata benda zhenskij rod, уaitu мелодрама, течка, dan дырка. Kata vasha mengacu pada kata utyrka.

\section{Bait Tiga}

В моём плеере педерасть

A на проводе террористь

Я читаю для тех, кто бродит

По рукам или по этапам

Я не требую понимания

Лишь один из шального люда

Понимает меня Иуда

V mojom pleere pederasty

A na provode terroristy

Ja chitaju dlja teh, kto brodit

Po rukam ili po jetapam

Ja ne trebuju ponimanija

Lish' odin iz shal'nogo ljuda

Ponimaet menja Iuda

Baris pertama dan kedua merupakan kalimat preposisi karena menggunakan preposisi $\mathrm{v}$ dan na 
yang menjelaskan keterangan tempat, yaitu pleere (diterjemahkan menjadi MP3) terkena kasus preposisi dan provode (kabel) terkena kasus preposisi. Lalu baris ketiga dan kelima merupakan kalimat sempurna yang mempunyai subjek predikat dan objek.

Ja menjadi subjek, chitaju dan ne trebuju menjadi predikat. Perbedaan diantara kedua kalimat itu berada pada objeknya. Baris ketiga memiliki objek tidak langsung yang dijelaskan menggunakan metafora, yaitu teh, kto brodit (mereka yang mengembara), sedangkan baris kelima memiliki objek langsung yaitu kata benda srednij rod, понимания (terkena kasus akusatif).

Baris keenam dan tujuh merupakan satu kalimat. On/ona yang dilesapkan kata kerja kala kini ponimaet (mengerti yang terkena konjugasi dari on/ona) pada baris ketujuh mengacu pada shal'nogo ljuda (orang gila) di baris keenam. Lalu Iuda merupakan objek yang dituju dari kedua kalimat tersebut.

\section{Refrain Dua}

Мухи в бокале вина, а

Что будет после меня, а

Мультики нового дня, $а$

Ты не разделишь со мной, ой

Кто из вас выдаст меня, а

Кто из вас выдаст меня, а

Кто-то заложит меня, а

Остьть не успеет косой, ой

Целую тебя, Иуда

Muhi v bokale vina, a

Chto budet posle menja, a

Mul'tiki novogo dnja, a

Ty ne razdelish' so mnoj, oj

Kto iz vas vydast menja, a

Kto iz vas vydast menja, a

Kto-to zalozhit menja, a

Ostyt' ne uspeet kosoj, oj

Celuju tebja, Iuda

Secara garis besar, refrain dua sama dengan refrain satu, yang membedakan kedua refrain tersebut adalah baris keempat, ketujuh, dan baris kesembilan. Pada baris keempat di refrain dua ini, konjugasi dari kata kerja yang akan datangnya berbeda dengan refrain satu, yaitu razdeljat (konjugasi dari oni) dengan razdelish' (konjugasi dari ty). Lalu pada baris ketujuh terdapat kata kerja yang akan datang zalozhit (konjugasi dari on/ona) yang mengacu pada kto-to (seseorang).
Terakhir pada baris kesembilan, yang juga merupakan kalimat penutup dari lagu berjudul Iuda ini, terdapat kata kerja masa kini Celuju (konjugasi Ja dari celovat') dan diikuti oleh kata ganti orang kedua berupa tebja (kasus akusatif).

Lirik lagu Iuda ini memiliki 10 kalimat metafora, 13 kata istilah, dan 2 kalimat anafora. Husky menggunakan rima a-a-b-b pada baris ke-empat hingga ke-tujuh di bait satu dan baris satu hingga keempat di bait dua. Kemudian, dia lebih banyak menggunakan kata kerja masa kini dan akan datang dibanding masa lampau. Berdasarkan hal tersebut peneliti berasumsi bahwa Husky menggunakan banyak metafora dan istilah untuk menutupi maksud tertentu dari apa yang ingin dia sampaikan.

\section{Praktik Diskursif}

Setelah menganalisis, tahap yang dilakukan selanjutnya adalah praktik atau analisis diskursif. Pada bagian ini, peneliti membagi fokus analisis menjadi latar belakang konteks, yaitu narkoba di Rusia, kemudian interpretasi teks menurut pola kalimatnya, dan hasil interpretasi teks.

Narkoba di Rusia

Narkoba sudah beredar di Rusia sejak awal abad ke20. Saat itu narkoba khususnya jenis morfin banyak digunakan oleh tentara Rusia untuk menjadi penawar rasa sakit ketika berperang. Selama perang terjadi, sulit untuk mencari rumah sakit yang tidak memiliki pasien terdiagnosis kecanduan narkoba jenis morfin.

Jenis kokain bahkan lebih populer saat itu. Sebelum peperangan, tepatnya pada akhir abad ke-19, kokain disebut sebagai "narkoba orang kaya" hingga narkoba jenis ini sempat dilegalkan dan dijual secara bebas di toko-toko obat. Menurut penelitian yang diadakan di Sankt Peterburg, pada tahun 1924 sekitar 70 hingga 80 persen tuna wisma telah atau masih menggunakan kokain [14].

Namun, pada tahun yang sama pemerintah mengeluarkan peraturan mengenai perdagangan narkoba untuk menanggulangi kecanduan narkoba yang menjadi momok di Rusia saat itu. Jika tertangkap, maka penjual akan dipidana selama 10 tahun.

Lain halnya dengan cannabis atau ganja. Di Rusia, penggunaan atau konsumsi ganja dianggap sebagai tindak kriminal. Peraturan ketat terhadap narkoba jenis itu melarang untuk memproduksi, menyimpan, dan menggunakan. Jika ada yang melanggar 
peraturan tersebut maka konsekuensinya adalah hukum pidana. Lama hukuman dan besarnya denda diakumulasi berdasarkan jumlah barang yang dimiliki.

Namun, hingga saat ini dukungan terhadap legalisasi ganja masih sering dikumandangkan. Pada bulan April di tahun 2017, Vladimir Pozner seorang tokoh media terkenal Rusia, menyatakan dukungannya terhadap legalisasi markoba jenis ganja. Dia mengatakan bahwa dengan melegalisasi ganja maka akan menurunkan tingkat kriminalitas terkait perdagangan obat-obatan ilegal. Meskipun mendapatkan dukungan dari banyak pihak, legalisasi ganja di Rusia masih menjadi hal yang mustahil. Pada tahun 2013, Pemerintah mengatakan dengan terbuka untuk tetap menentang legalisasi mariyuana atau ganja.

\section{Interpretasi Teks}

Iuda karya Husky ini memiliki banyak penggalan kalimat untuk menyesuaikan rimanya dalam satu bait. Penulisan lirik ini tidak terbatas pada kelengkapan struktur kalimat. Peneliti menemukan total 33 kalimat berdasarkan penggalan rima (tidak termasuk kalimat yang sama) di dalam lagu Iuda, namun karena keterbatasan kata yang harus diteliti pada penelitian ini, maka peneliti hanya akan menginterpretasikan 6 kalimat yang berhubungan dengan konteks, yaitu representasi narkotika.

1. И как-то так выходит, что без этого... ну, ты не можешь жить. Это как пища, как воздух. (I kak-to tak vyhodit, chto bez jetogo... nu, ty ne mozhesh' zhit'. Jeto kak pishha, kak vozduh.)

Lagu ini dimulai dengan penggambaran tentang bagaimana sifat kecanduan seorang pecandu narkoba melalui latar belakang suara yang disamarkan dengan suara berat. Berdasarkan hasil terjemahan mandiri, peneliti berasumsi bahwa kalimat tersebut adalah pernyataan yang dikeluarkan oleh seorang pecandu narkoba untuk menunjukkan bagaimana dia menganggap obat-obatan itu sebagai bagian dari hidupnya.

Pada kalimat I kak-to tak vyhodit, chto bez jetogo, terlihat Husky ingin menyampaikan pertanyaan tentang bagaimana jika "pecandu" tersebut (diwakilkan dengan kata Ty) tidak mendapatkan atau memakai narkoba. Lalu di kalimat setelahnya, Husky membenarkan bahwa ternyata mereka tidak bisa hidup tanpa obat-obatan itu. Kemudian kalimat Jeto kak pishha, kak vozduh memperkuat pernyataan bahwa mereka sudah menjadikan obat-obatan tersebut sebagai bagian dari hidupnya.

\section{2. Пусть в такси шепелявит ретро; $\mathrm{Mbl}$ c водилой раздавим пятку \\ (Pust' v taksi shepeljavit retro, my s vodiloj razdavim pjatku.)}

Berdasarkan anotasi lirik pada laman daring [15], sebagian besar taksi di Rusia memutar lagu-lagu retro lama selama perjalanannya. Namun, peneliti berasumsi bahwa kata retro pada kalimat tersebut mengacu pada salah satu nama penyiaran radio di Rusia, yaitu RetroFM. Setelah diterjemahkan, kata taksi shepeljavit retro diartikan menjadi "Biarkan retrofm yang tidak jelas itu berbunyi", namun kata kerja shepeljavit mempunyai maksud tersendiri, yaitu "berbicara tidak jelas".

Peneliti berasumsi bahwa pada kalimat ini, Husky ingin menjelaskan bahwa "dia" yang dilesapkan merujuk pada kata retro. Kemudian shepeljavit digunakan karena ketika seseorang menggunakan obat-obatan mereka menjadi tidak fokus, mungkin karena itu suara musik retro yang diputar dalam taksi menjadi terdengar tidak jelas. Menurut data BNN, salah satu ciri-ciri pengguna narkoba adalah kesulitan untuk fokus.

Pada kalimat selanjutnya Husky menyampaikan bahwa tokoh "aku" dengan "dia" yang diwakilkan kata my (kita) bersama dengan supir taksi tersebut memakai narkotika. Di dalam liriknya, Husky menggunakan kata pjatku untuk menyamarkan kata narkotika. Pjatku sendiri mempunyai banyak makna tergantung dari konteksnya, misal dalam konteks hitungan dapat diartikan sebagai seperlima. Berdasarkan konteks keseluruhan dari lirik ini, maka peneliti menginterpretasikan kata tersebut dengan narkotika yang dilinting berbentuk rokok.

\section{3. Мухи в бокале вина, а; Что будет после меня, a}

(Muhi v bokale vina, Chto budet posle menja)

Berdasarkan anotasi laman daring Genius, kalimat muhi $\mathrm{v}$ bokale vina merupakan sebuah metafora untuk orang-orang yang sedang dalam situasi tidak punya harapan karena pernah menggunakan narkotika dengan cara tertentu. Kemudian kalimat chto budet posle menja adalah ungkapan yang dirasakan bagi subjek yang dimaksud pada kalimat sebelumnya mengenai perasaan mereka. Mereka berandai-andai tentang apa yang menanti mereka di masa depan 
4. Вы простите меня, утырка: Мне скучны ваша мелодрама, ваша течка и ваша дырка (a)

(Vy prostite menja, utyrka: mne skuchny vasha melodrama, vasha techka i vasha dyrka.)

Pada kalimat tersebut peneliti menemukan penjelasan mengenai tokoh $\mathrm{Vy}$. Hal itu terlihat ketika tokoh menja meminta maaf kepada tokoh $\mathrm{Vy}$ yang merupakan utyrka. Utyrka dapat diartikan sebagai orang yang tidak berguna. Tokoh "aku" meminta maaf karena dia telah bosan atas semua perbuatan utyrka, yaitu melodrama, gairah seksual, dan lubang. Lubang yang dimaksud di sini juga dapat diartikan sebagai vagina.

Banyak pengguna narkoba yang terlibat sebagai pekerja seks, baik itu laki-laki ataupun perempuan [16]. Menurut data yang peneliti kutip dari laman Institut Penyalahgunaan Narkoba Nasional (NIDA), pada tahun 2007-2008 data yang terdiri dari 665 pekerja seks perempuan Petersburg dan 231 pekerja seks perempuan Orenburg, $73 \%$ dari semua pekerja seks tersebut pernah terlibat dalam penggunaan narkoba, jenisnya $89.5 \%$ adalah ganja, $75.6 \%$ opiat, dan $70.9 \%$ adalah obat-obatan lainnya.

Dalam beberapa kasus, $49 \%$ orang telah menggunakan narkoba sebelum menjadi pekerja seks komersial, $29.5 \%$ dalam interval waktu yang sama, dan hanya $1.9 \%$ yang baru menggunakan narkoba setelah menjadi pekerja seks. Lalu menurut data, sekitar $20.3 \%$ pekerja seks pernah mencoba untuk berhenti satu kali, $45.5 \%$ mencoba dua hingga tiga kali, $33.9 \%$ lebih dari tiga kali, dan hanya $10.6 \%$ pekerja seks yang berhasil berhenti.

\section{5. Я читаю для тех, кто бродит; По рукам или по этапам}

(Ja chitaju dlja teh, kto brodit, po rukam ili po jetapam.)

Husky menjelaskan bahwa dia membaca (lirik lagu ini) hanya untuk orang-orang yang mengerti dirinya, yaitu orang yang sedang mengembara. Mengembara yang dimaksud tersirat pada kalimat setelahnya.

Dijelaskan oleh anotasi lirik pada laman daring Genius bahwa kata po rukam yang dimaksud adalah orang-orang yang menyuntikkan obat-obatan atau narkoba menggunakan jarum. Lalu kata-kata po jetapam dimaksudkan untuk orang-orang yang sedang dalam masa tahanan sebagai kriminal.

6. Я не требую понимания; Лищь один из шального люда; Понимает меня Иуда
(Ja ne trebuju ponimanija, lish' odin iz shal'nogo ljuda, ponimaet menja iuda.)

Pada kalimat ini, tokoh Ja, yaitu Husky, menjelaskan bahwa dia tidak perlu semua orang untuk mengerti dirinya, karena lagu ini ditujukan hanya untuk orang-orang yang mengembara. Pada kalimat tersebut terlihat bahwa tokoh menja, yaitu Husky seperti sedang berbicara dengan Iuda.

\section{Hasil Interpretasi Teks}

Lagu berjudul Iuda ini dibuat pada tanggal 18 April 2018. Musik video lagu ini dilarang tayang di situs YouTube oleh pemerintah pada tanggal 19 November 2018. Pemerintah melarang musik video ini ditayangkan karena dugaan propaganda atas distribusi obat-obatan dan penggunaannya.

Lagu ini berisi penggambaran pengguna narkoba yang berkembang pesat di Rusia melalui tiga tokoh, yaitu Ja, Vy, dan Ty. Penggambaran tersebut dapat dilihat melalui liriknya yang menyinggung sifat ketakutan, kecemasan, dan keresahan yang ditunjukkan oleh tokoh "kamu" dan "aku" di bagian refrain. Tokoh "kamu" dan "Anda" merupakan perwakilan dari sifat buruk masyarakat yang telah masuk ke industri perdagangan narkoba.

Penggunaan bahasa dalam lirik lagu Iuda sebagai sebuah wacana tentunya akan menentukan sikap dan opini pendengarnya. Husky dalam penulisan liriknya mengadapatasi rapper Amerika dan menggabungkannya dengan kesuraman dan kemurungan yang telah didefinisikan sebagai sastra Rusia sejak zaman Tolstoy dan Dostoevsky [7].

Pilihan kata dan frasa yang ada di dalam lirik tersebut akan memengaruhi respon pendengar terhadap informasi yang disampaikan. Oleh karena itu, sebuah kata dan frasa dapat memunculkan suatu relasi kuasa, representasi baik, buruk, maupun netral. Dalam hal ini, Husky memberikan representasi baik serta buruk pada pendengarnya. Hal tersebut dapat dilihat pada liriknya yang berkesan buruk, namun jika dipahami, terlihat bahwa Husky berusaha untuk mengingatkan kepada seluruh pendengar lagunya untuk tidak memasuki dunia tersebut.

\section{Praksis Sosial-Budaya}

Peneliti telah menjelaskan bahwa lagu Iuda ini telah dilarang tayang oleh pemerintah Rusia karena representasi narkoba dalam bentuk lirik yang disajikan di dalamnya. Pemerintah melakukan tindakan tersebut pada bulan November tahun 2018, 
ketika Husky sedang tertimpa banyak masalah. Pada bulan November di tahun itu, setelah musik videonya diblokir oleh pemerintah, konsernya juga dibatalkan karena tuduhan mengandung "ekstremisme".

Kemudian di bulan yang sama dia sempat dipenjarakan selama 12 hari karena tuduhan hooliganism, yaitu menyanyikan satu bait lagu Ai di atas sebuah mobil yang terparkir di kota Krasnodar. Selama masa tahanan dia juga menolak melakukan tes urin untuk narkoba dan alkohol.

Husky dikenal sebagai seorang rapper yang tidak pernah takut untuk mengutarakan pikirannya. Pada tahun 2011 silam, lagu debutnya dengan judul Sed'moe oktjabrja berisi mengenai kritik terhadap politisi Rusia, Vladimir Putin, yang dianggap sebagai "tsar, yang meminum darah orang-orang tertindas, melecehkannya, dan ditinggalkan" [17]. Dia juga sempat terang-terangan menghapus seluruh album keduanya. Hal itu dia lakukan sama persis dengan Nikolai Gogol saat membakar bagian kedua dari novelnya yang berjudul "Jiwa-jiwa Mati". Kemudian Husky melakukan sebuah sandiwara bertemakan "bunuh diri" dengan menggantungkan manekin pada sebuah jendela di hotel daerah Lapangan Merah lengkap dengan baju yang biasa digunakan olehnya. Pada manekin tersebut terdapat tulisan "kematian seorang rapper bernama Husky" [7].

Hal yang dilakukannya tersebut mengundang perhatian pemerintah. "If it is impossible to stop, then we need to lead, and in an appropriate way, direct" (Putin, 2018). Kalimat tersebut dikatakan oleh Putin kepada dewan penasihat budayanya di pertemuan St. Petersburg dalam rangka membahas dukungan negara untuk karya seni. Vladimir Putin mengatakan bahwa musik rap ini didasari oleh tiga pilar, yaitu seks, narkoba, dan protes, namun hal yang sangat dikhawatirkan oleh Putin adalah narkoba, karena menurutnya hal tersebutlah yang dapat menurunkan martabat sebuah negara.

Setelah pertemuan tersebut terlaksana, penganiayaan terhadap rapper di Rusia telah berhenti sampai saat ini, namun berbeda untuk Husky. Para politisi menudingnya memimpin pemuda Rusia ke jalan yang sesat dan menggambarkannya sebagai orang menyimpang yang tujuannya hanya untuk menggambarkan Rusia dengan cara yang buruk [7]. Gambaran peneliti mengenai Husky berbanding terbalik dengan pernyataan tersebut. Dia merupakan orang yang jujur, dia tidak menutup-nutupi suatu hal atau berpura-pura bahwa Rusia tidak memiliki masalah.

Seperti dalam lirik lagu Iuda ini, Husky menggambarkan dan merepresentasikan kerusakan Rusia dalam konteks narkoba atau obat-obatan yang mungkin tidak diketahui oleh semua orang. Rusia memiliki undang-undang narkoba yang kejam, yaitu di pasal 228 KUHP yang mengatur pembelian, kepemilikan, distribusi, produksi, dan pemrosesan obat-obatan. Alih-alih membantu pengguna narkoba, penegak hukum sering menggunakan hukum kejam untuk keuntungan mereka sendiri. Mereka memburu pengguna narkoba hanya untuk memenuhi kuota dan mendapatkan bonus, bahkan demi hal tersebut, mereka bisa saja menuduh orang yang tidak menggunakan narkoba dengan cara menyelundupkannya ke dalam barang orang tersebut dan kasus-kasus tersebut tidak pernah didokumentasikan [18].

\section{KESIMPULAN}

Lagu Iuda memiliki hal menarik dalam segi cerita yang tersirat serta penggambaran mengenai sifatsifat pengguna narkoba di Rusia melalui tokoh Ja, Ty, dan Vy. Husky yang merupakan tokoh Ja menyebut Yudas dengan sebutan Ty dan menyebut pengguna narkoba dengan sebutan $\mathrm{Vy}$. Peneliti berkesimpulan bahwa lagu ini merepresentasikan pengguna narkoba berdasarkan tokoh-tokoh tersebut.

Dalam lagu ini ditemukan adanya representasi buruk mengenai pengguna narkoba, seperti sifat candu mereka yang dapat mengakibatkan tindak kriminal. Hal tersebutlah yang ditakutkan oleh Presiden Rusia, Vladimir Putin, yaitu tingginya angka pengguna narkoba dapat menyebabkan degradasi negara. Sifat-sifat lainnya juga dapat berpengaruh buruk untuk tingkat kesehatan negara, seperti mudah kehilangan fokus, kecemasan dan keresahan yang dapat menimbulkan keinginan untuk bunuh diri.

Sebaliknya, di dalam lagu ini juga ditemukan adanya representasi baik mengenai pengguna narkoba. Husky melihat sisi lain dari pengguna narkoba, karena berdasarkan latar belakangnya, dia telah tumbuh di dalam lingkungan yang seperti itu. Sisi lain yang dia lihat adalah sisi di mana mereka, pengguna narkoba, sangat membutuhkan pertolongan, bukan penyiksaan secara verbal maupun sosial yang selama ini terjadi. 
Selain itu, dengan melihat konteks dan kepentingan dalam lagu Iuda ini, Rusia, khususnya pemerintah, merasa cemas terhadap kaum pemudanya. Lagu ini mengandung konteks narkoba yang cukup kuat dan jelas. Hal tersebut mengakibatkan lagu ini telah dilarang untuk tayang di Rusia secara menyeluruh. Namun hal ini tidak mempengaruhi Husky. Meskipun dia sudah pernah menjadi sorotan pemerintah dan ditangkap, dia tetap terus membuat karya yang dianggap membongkar masalah-masalah yang ada di Rusia.

\section{REFERENSI}

[1] E. A. Hewett and V. H. Winston, Milestones in Glasnost and Perestroyka, Woshington D.C: Brooking Institution, 1991.

[2] A. Osipovich, "Russian Rap Inspires a Movement," The Wall Street Journal, 24 Juli 2010.

[3] P. Ewell, "Russian Rap in the Era of Vladimir Putin. In M. Miszczynski, \&. Helbig, Hip Hop at Europe's Edge: Music, agency, and Social Change (pp.45-62)," Indiana University Press, Indiana, 2017.

[4] A. P \& L. Hosp, "Russia's War on Youth," Freedom House, https://freedomhouse.org/ article/russias-war-youth, 2019.

[5] A. Chernyshev, "Призывы к Измене Родине". Как Депутат из Ленобласти Взялся за Рэперов.," Риа Новости, 08 November 2018.

[6] L. Bershidsky, "Russian Rappers Give Up on Putin," Bloomberg Opinion, pp. https://www.bloomberg.com/opinion/articles /2018-12-14/russian-rappers-give-up-onputin, 14 Desember 2018.

[7] T. Waugh, "Who Let The Dog Out: Husky and the Regeneration of Russian Rap.," Kollektivmsk, pp. https://www.kollektivmsk .com/features/russian-rapper-huskycontroversy/, 7 Agustus 2019.
[8] S. Hall, Representation: Cultural Representations and Signifying Practices., London: Sage Publication., 1997.

[9] N. Fairclough, Analysis Discourse: Textual Analysis for Sosial Research, Psychology Press, 2003.

[10] L. Phillips \& M. Jorgensen, Discourse Analysis as Theory and Method, London: Sage Publication Ltd., 2002.

[11] N. Fairclough, Critical Discourse Analysis, London: Sage, 2013.

[12] Haryatmoko, Critical Discourse Analysis (Analisis Wacana Kritis): Landasan Teori, Metodologi dan Penerapan, Jakarta: Rajawali Pers, 2017.

[13] G. Yule, Pragmatics, New York: Oxford University Press, 1996.

[14] O. Yegorov, "Sejarah: Rusia Era Revolusi, Negara yang Kecanduan Narkoba," Russia Beyond, pp. https://id.rbth.com/sejarah/2017/08/21/sejara h-rusia-era-revolusi-negara-yang-kecanduannarkoba_qyx825798, 21 Agustus 2017.

[15] G. Rindner, "Vladimir Putin Wants Russian Government To Be In Charge Of Rap Music," Genius, pp. https://genius.com/a/vladimirputin-wants-russian-government-to-be-incharge-of-rap-music, 2018 Desember 2018.

[16] A. Sarang, T. Rhodes, N. Sheon and K. Page, "Policing drug users in Russia: risk, fear, and structural violence," National Library of Medicine, vol. 45, no. 6, pp. 813-864, 2010.

[17] Husky, "Russian rapper jailed for street gig after venue ban," BBC, pp. https://www.bbc.com/news/world-europe46309271, 18 November 2018.

[18] A. Kauschanski, "Drug addiction in Russia: Draconian laws instead of help," DW Made for Minds, pp. https://www.dw.com/en/drugaddiction-in-russia-draconian-laws-insteadof-help/a-51193559, 11 November 2019. 